\title{
Air pollution in Iran
}

\section{Caroline Mawer urgent care GP}

London, UK

Brauer and Mancini say that "nowhere are the health effects of outdoor air pollution felt more than in China."

But four of the top 10 air polluted cities are in Iran. Ahvaz is the most polluted city in the world, with particulate levels three times that of Beijing, and nearly 13 times that of London. ${ }^{2}$ Ahvaz struggles with micro-dust blowing in from neighbouring countries, as well as industrial and domestic pollution.

Tehran has cleaned up recently, with carbon monoxide levels no longer a problem, lead eliminated from gasoline, and sulphur levels dropping from a frightening 8000 parts per million (ppm) to less than $200 \mathrm{ppm}$ (they are aiming at $<10$ ). But a third of days in Tehran are still officially "unhealthy." It's worse for the vulnerable-schools are often closed.

Sanctions make it difficult for Iranians to improve things: petroleum sanctions mean they are forced to use their own "wrong sort of petrol" for everything. Financial sanctions mean that there is no money for "best available technology," even if imports were allowed. So they can't retrofit urban buses or think about hybrid electric taxis and motorbikes, as they would like to. They can't even import the calibration gases needed for their monitoring programme. ${ }^{3}$ At a recent Iran Heritage Foundation conference, there was talk of donkeys smuggling these high technology gases over the mountain borders.
Micro-dust is also "exported" from Iran. The complete drying out of Iran's third largest lake (once $388500 \mathrm{~km}^{2}$ ) has led to major population movements, with many adverse health effects. The consequent dust blows hundreds of kilometres into the eyes and lungs of those in Pakistan and Afghanistan. ${ }^{56}$

So it's not just China experiencing adverse health effects from air pollution, even if the less official academic sanctions make it difficult for Iranian scientists to share their data.

\section{Competing interests: None declared.}

Full response at: www.bmj.com/content/348/bmj.g40/rr/685423.

Brauer M, Mancini GBJ. Where there's smoke ... BMJ 2014;348:g40. (21 January.)

2 WHO. Database: outdoor air pollution in cities: 2003-10. www.who.int/phe/health_topics/ outdoorair/databases/en/.

3 Hosseini V. Air pollution: causes, effects and mitigating measures. Presented at Iran's Natural Heritage: A Catalyst Symposium to Spark Measurable Change, 18-19 January 2014. www.youtube.com/embed/nJKgufsEgl8.

4 Iran Heritage. Conference summary. 2014. www.iranheritage.org/Ecology/.

5 Lewis G. Saving the imperiled Hamouns of Eastern Iran. UNDP, 2014. www.ir.undp.org/ content/iran/en/home/presscenter/articles/2014/02/02/saving-the-imperiled-hamouns-ofeastern-iran-l

6 Mawer C. Iran's natural heritage: the export of dust. 2014. www.carolinemawer.com/whatsnew/export-dust/.

Cite this as: BMJ 2014;348:g1586

๑ BMJ Publishing Group Ltd 2014 